Historic, Archive Document

Do not assume content reflects current scientific knowledge, policies, or practices. 


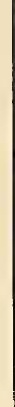




\section{Propagation and Storage of Neoaplectana carpocapsae Weiser Using Amyelois transitella (Walker) Adults}

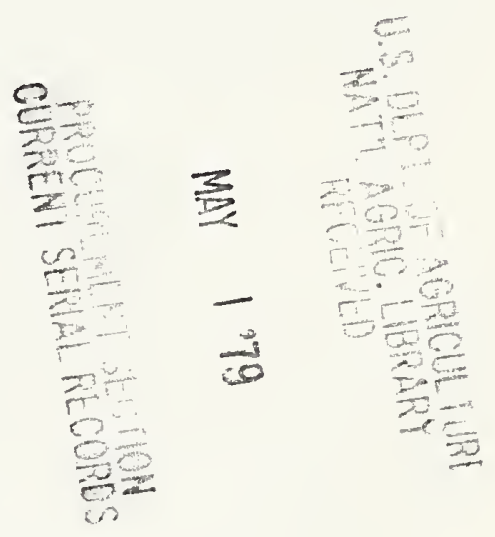

U.S. Department of Agriculture Science and Education Administration Advances in Agricultural Technology • AAT-W-3/February 1979 


\section{ABSTRACT}

Describes a technique for using adult Lepidoptera in the simple, economical rearing of Neoaplectana carpocapsae and other entomogenous nematodes. The resultant invasive stage nematodes are stored without mechanical aeration at $6{ }^{\circ} \mathrm{C}$ in compact, stackable, plastic petri dishes.

KEYWORDS: Entomogenous nematodes, Neoaplectana carpocapsae; propagation and storage; Lepidoptera adult hosts, navel orangeworm adults.

A free copy of this publication is available from the StoredProduct Insects Research Laboratory, 5578 Air Terminal Drive, Fresno, Calif. 93727 .

Science and Education Administration, Advances in Agricultural Technology, Western Series, No. 3, February 1979 


\section{$2^{4} \quad b c^{1}$, b \\ PROPAGATION AND STORAGE OF, NEOAPLECTANA CARPOCAPSAE WEISER

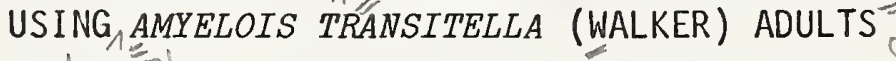 $b c 276$ \\ By James E. Lindegren, Darlene F. Hoffmann, Susan S. Collier and Rodney D. Fries ${ }^{l}$}

\section{INTRODUCTION}

The insect parasitic nematode Neoaplectana carpocapsae Weiser has been reared on artificial diets $(1,2,4,5,6,9)^{2}$ as well as in lepidopteran larvae $(2,8)$. The low rearing cost of 2 cents per million nematodes reported by Bedding ( 1 ), as compared with $\$ 1$ per million reported by Poinar ( 7 ), favors the use of artificial diets for the rearing of this nematode. Rearing methods utilizing insect hosts described by Dutky et al.(2) and Poinar (8), however, are useful for isolating and maintaining new and possibly obligate insect parasitic nematodes, as well as for rearing limited numbers of nematodes for laboratory or small scale field tests. Work in this area has prompted the following modifications of the simplified rearing method described by Poinar ( 8$)$.

\section{NEMATODE REARING}

Navel orangeworm, Amyelois transitella (Walker), adults reared on a modified bran diet, 3 described by Finney and Brinkman (3), are substituted for last instar wax moth larvae as an insect host for $N$. carpocapsae. The adults inactivated by storage at $4^{\circ} \mathrm{C}$ for $1 \mathrm{~h}$ are then added to $100-$ by $15-\mathrm{mm}$ plastic petri dishes containing four filter papers ${ }^{4}$ premoistened with $4 \mathrm{ml} 0.1$ percent formalin solution, prepared with 37.8 percent formaldehyde and deionized water and one drop of concentrated (about 15,000) invasive stage nematodes ( $\mathrm{fig} \cdot 1$ ). 5 The adults are then incubated at $27^{\circ} \mathrm{C}$ for $48 \mathrm{~h}$ (fig. 2). The bottom of the exposure

lResearch entomologist and biological laboratory technicians, respectively, Stored-Product Insects Research Laboratory, 5578 Air Terminal Drive, Fresno, Calif. 93727.

2Italic numbers in parentheses refer to Literature Cited, p. 3 .

${ }^{3}$ The raw bran used in this diet was autoclaved to prevent insect pathogen contamination and a solution of Nutritional Biochemical Corporation Vitamin Diet Fortification Mixture was added to help replace heat labile vitamins lost during sterilization.

${ }^{4}$ No. 1 qualitative 7 -cm-diameter Whatman.

$5_{F i g u r e s}$ follow at the end of the report. 
petri dish, containing the dead parasitized $A$. transitella adults, is then placed inside a $150-$ by $25-\mathrm{mm}$ plastic petri dish, containing $25 \mathrm{ml}$ of 0.1 percent formalin solution. Invasive stage nematodes are then trapped in the formalin solution as they move out of the exposure petri dish (fig. 3 ). The trapped nematodes are harvested in glass settling flasks (fig. 4) 1 week after the initial host exposure and biweekly thereafter for 4 to 6 weeks.

Two $\mathrm{ml}$ of concentrated nematodes (about $3 \times 10^{6}$ per $\mathrm{ml}$ ) are then transferred with a disposable pipette to a $150-$ by $15-\mathrm{mm}$ plastic petri dish containing $25 \mathrm{ml}$ of 0.1 percent formalin solution. The nematodes are then stored at $6^{\circ} \mathrm{C}$ (fig. 5) until needed.

Formalin solution must be added periodically to replace evaporated moisture. The solution level should be 2 to $3 \mathrm{~cm}$ deep to allow for oxygen exchange. Concentrations of $N$. Carpocapsae invasive stages, up to 4 million per petri dish, have, to date, remained about 94-percent viable for 9 months under these storage conditions. An overall view of this procedure is presented in figure 6 .

\section{RESULTS AND DISCUSSION}

The average nematode production per adult from the 1,325 navel orangeworm adults sampled biweekly for 6 weeks is 7,000 with 91 percent of the total nematode production occurring within the first 3 weeks of the sampling period.

As a result of a multidisciplinary approach to control the navel orangeworm, a multimillion dollar pest of almonds in California, about 6,000 nave 1 orangeworm adults are produced per week at this laboratory. The nematode production capability is therefore about 42 million nematodes per week.

Navel orangeworm adults and other adult Lepidoptera either salvaged as byproducts from insect rearing or possibly collected from light traps represent a low cost food source for rearing entomogenous nematodes. At this facility, entomogenous nematodes have been reared on navel orangeworm adults since 1976. Nematodes successfully reared with this sytem include the Mexican and DD136 strain of Neoaplectana carpocapsae, $N$. glasseri Steiner, and Heterorhabditis heliothidis (Khan, Brook, and Hirschmann).

\section{SUMMARY}

Adult Lepidoptera provide a previously unutilized food source for the rearing of $N$. carpocapsae and other entomogenous nematodes.

The advantages of this rearing and storage system are: (1) It is economical if cost free adult Lepidoptera are utilized, (2) it provides a clean culture of invasive stages, ( 3 ) it is adaptable to the isolation and maintenance of other entomogenous nematodes, and (4) it provides for the concentrated sim plified storage of the harvested invasive stage nematodes. 
(1) Bedding, R. A.

1967. New methods increase the feasibility of using Neoaplectana spp. (Nematode) for the control of insect pests. Proc. Int. Colloq. Invert. Pathol.: 250-254.

(2) Dutky, S. R., Thompson, J. V., and Cantwe11, G. E.

1964. A technique for the mass propagation of the DD-136 nematode. J. Insect. Patho1. 6: 417-422.

(3) Finney, G. L., and Brinkman, D.

1967. Rearing the navel orangeworm in the laboratory. J. Econ. Ent. 60: 1109-1111.

(4) Glaser, R. W., McCoy, E. E., and Girth, H. B.

1942. The biology and culture of Neoaplectana chresima, a new nematode parasite in insects. Proc. Roy. Soc. Queens1. 28: 123-126.

(5) Hansen, E. L., Yarwood, E. A., Jackson, G. T., and Poinar, G. 0., Jr. 1968. Axenic culture of Neoaplectana carpocapsae in liquid media. J. Parasitol. 54: 1236-1237.

(6) House, H. L., Welch, H. E., and Cleugh, T. R.

1965. Food medium of prepared dog biscuit for the mass production of the nematode DD-136 (Nematode: Steinernematidae). Nature (London) 206: 847 .

(7) Poinar, G. O., Jr.

1971. Use of nematodes for microbial control of insects. Pp. 181-203. H. D. Burges and N. W. Hussey, eds., In Microbial Control of Insects and Mites, Academic Press, New York. 861 pp.

(8) Poinar, G. O., Jr.

1975. Entomogenous nematode, a manual and host list of insect-nematode associations. E. J. Bril1, Leiden, The Netherlands. 317 pp.

(9) Poinar, G. O., Jr. and Thomas, G. M.

1966. Significance of Achromobactor nematophilus Poinar and Thomas (Achromobacteraceae: Eubacteriales) in the development of the nematode, DD-136 (Neoaplectana sp. Steinarnematidae). Parasitology 56: 385-390. 


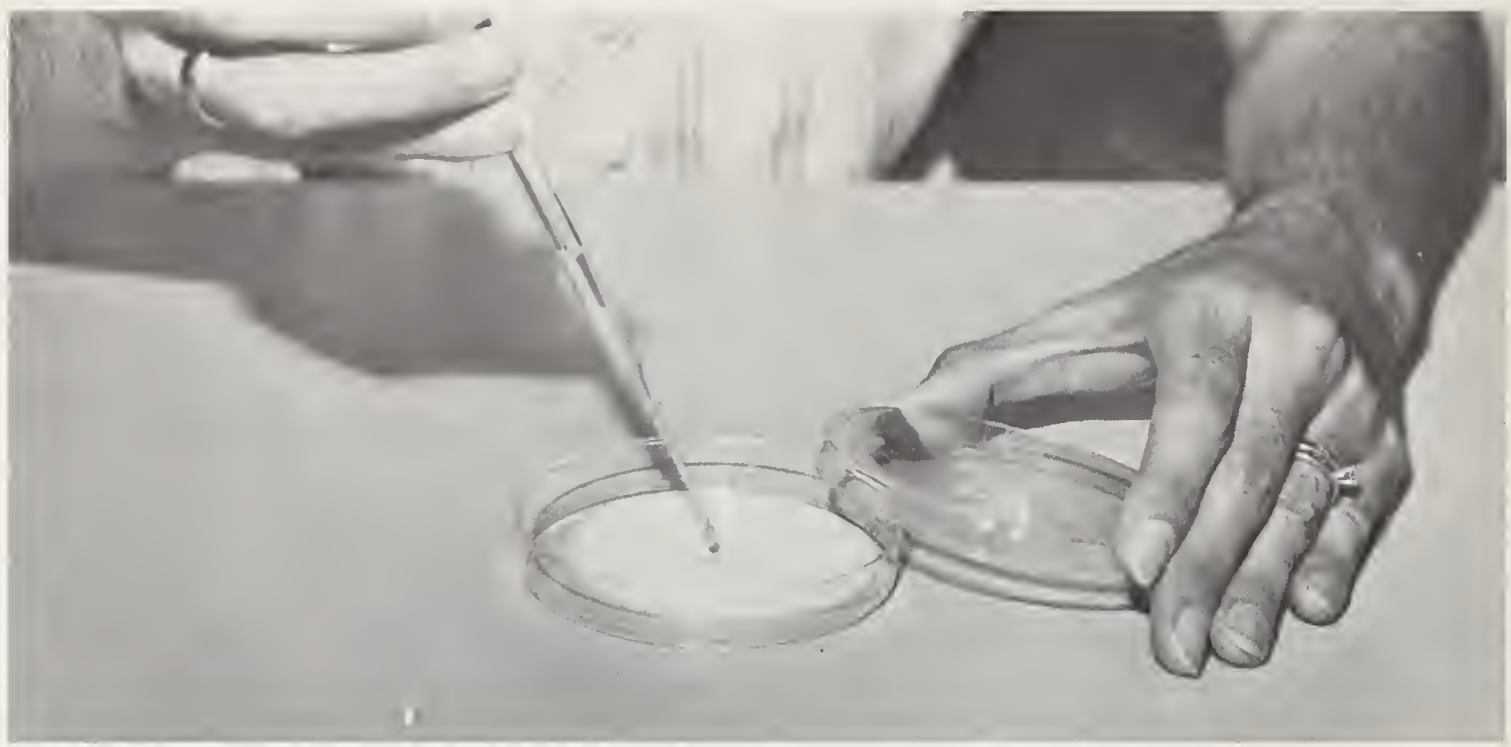

Figure 1.--Adding $N$. carpocapsae invasive stages to exposure petri dish.

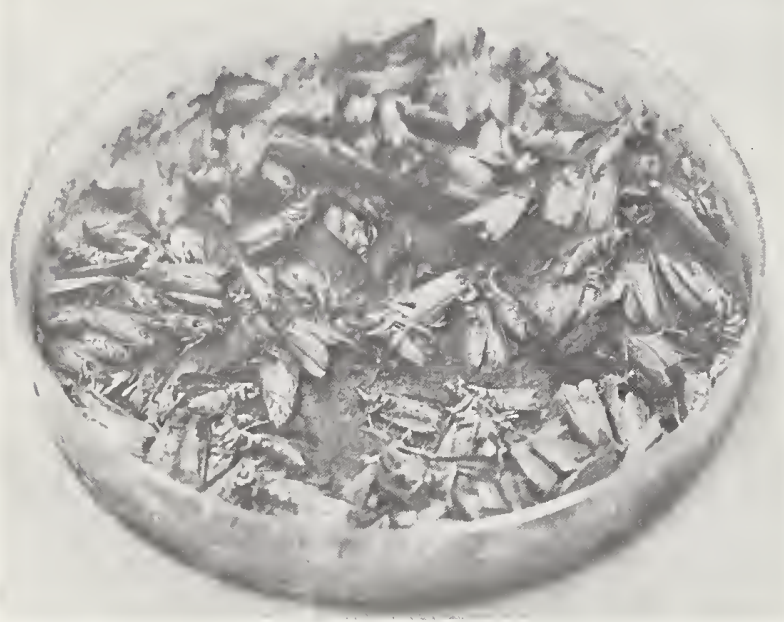

Figure 2.--Dead parasitized naval orangeworm adults $48 \mathrm{~h}$ after exposure to nematodes.

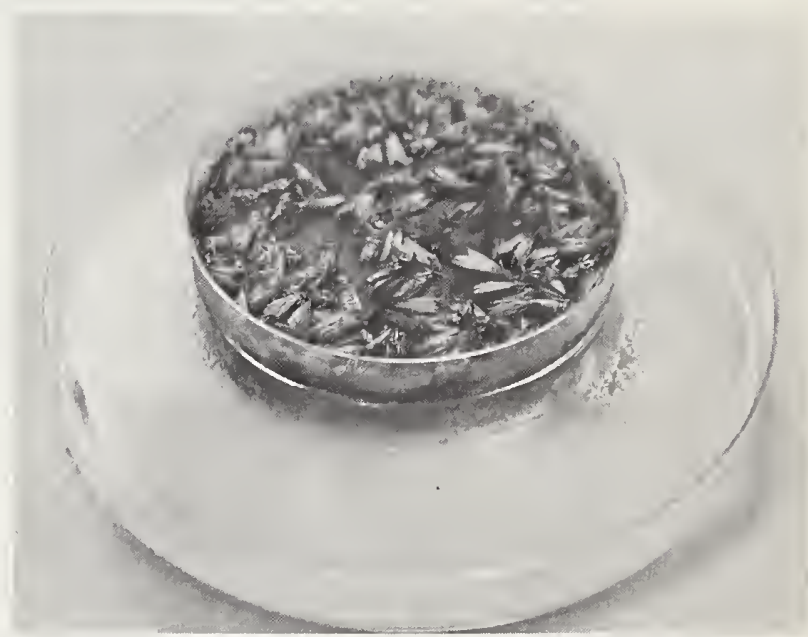

Figure 3.--Invasive stage nematodes migrating from parasitized naval orangeworm adults into formalin solution. 


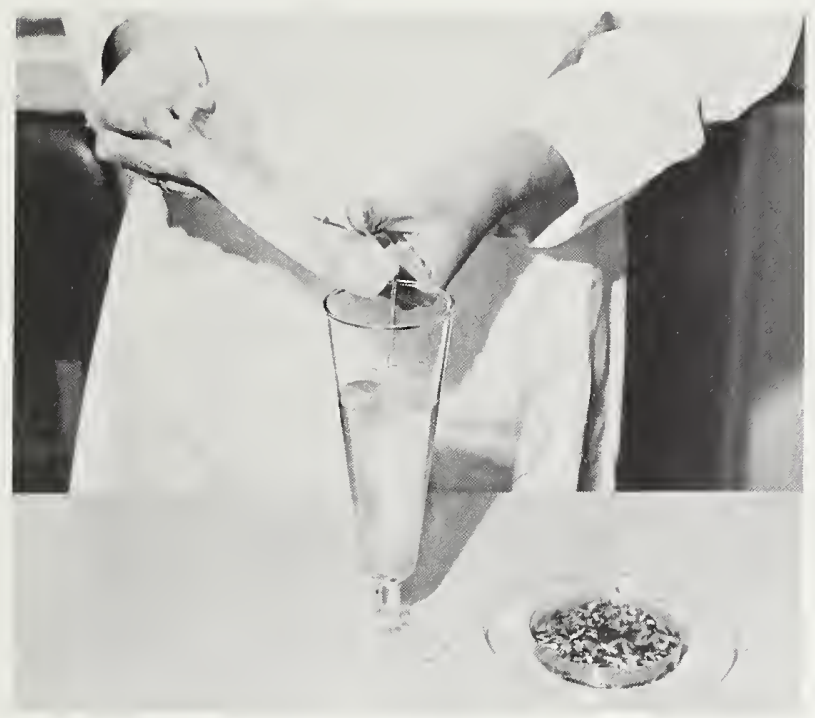

Figure 4.--Invasive stage nematodes trapped in formalin solution are settled for storage.

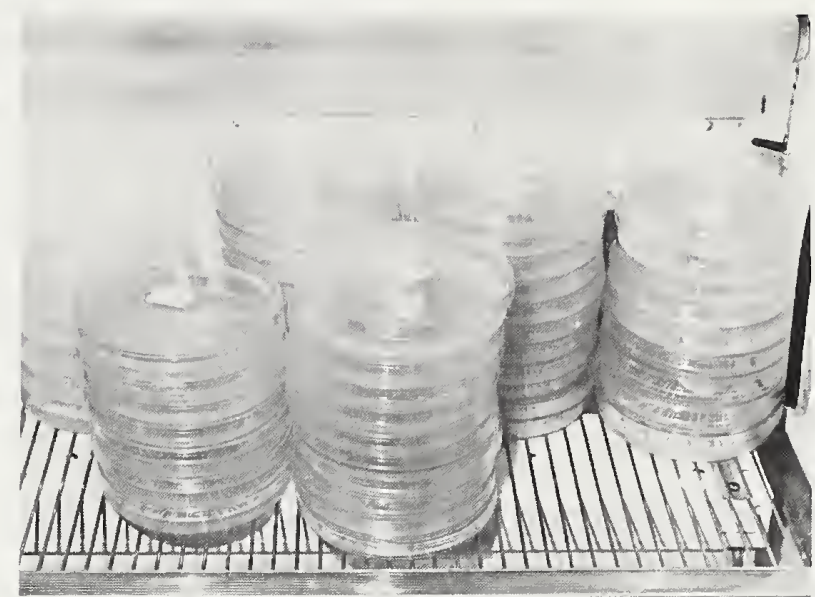

Figure 5.--Concentrated invasive stage nematodes (about 6 million per petri dish) stored at $6^{\circ} \mathrm{C}$.

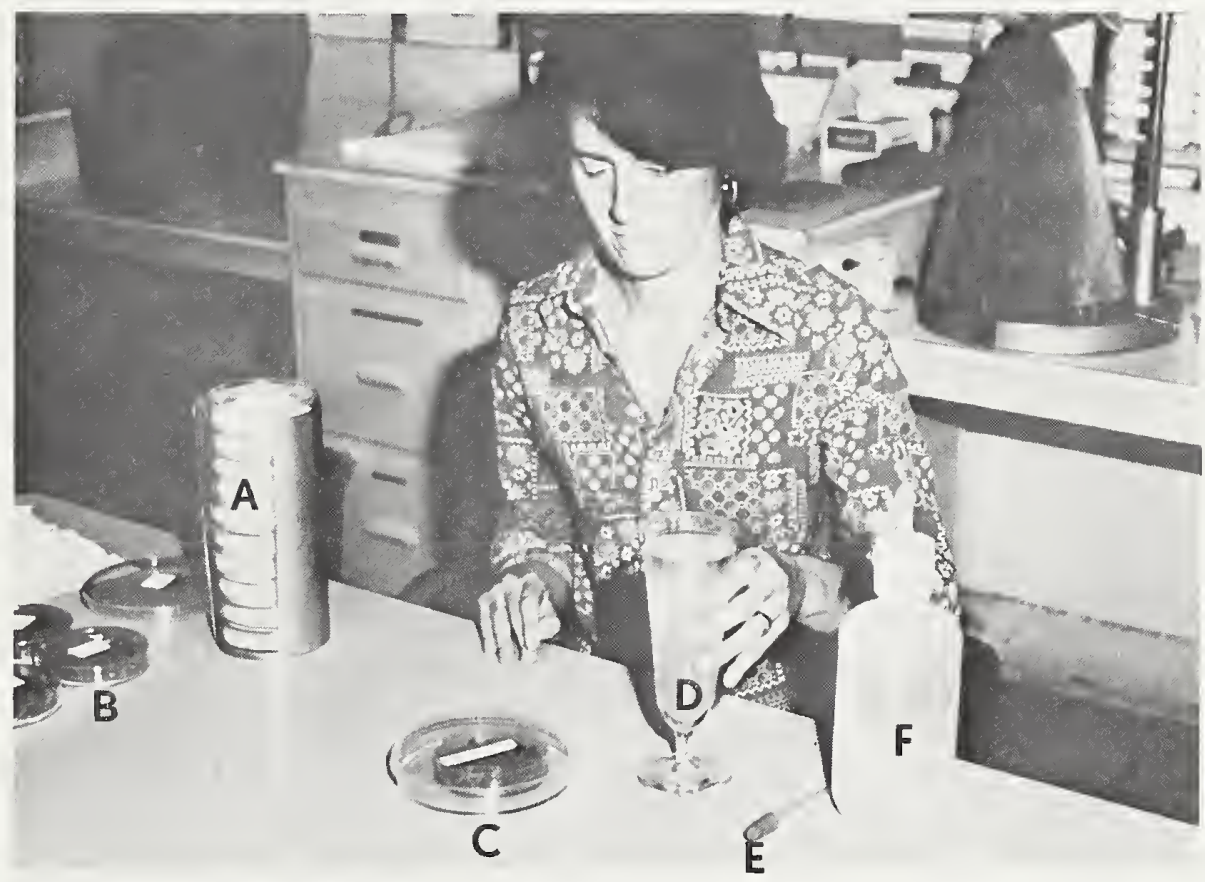

Figure 6.--Overview of nematode rearing procedure: $A$, Exposure dishes with about 15,000 nematodes and $4 \mathrm{ml} 0.1$ percent formalin solution can be stored at $6^{\circ} \mathrm{C}$ until needed; $B$, exposure dishes $48 \mathrm{~h}$ after the addition of navel orangeworm adults; $C$, bottom half of exposure dish in 150- by 25- mm trapping dish with invasive stage nematodes in 0.1 percent formalin solution; $D$, settling flask with nematodes starting to collect at the bottom; $E$, disposable pipette for transferring concentrated nematodes; $F$, formalin (0.1 percent) solution dispenser. 
U. S. DEPARTMENT OF AGRICULTURE

SCIENCE and EDUCATION ADMINISTRATION

WESTERN REGION

2850 TELEGRAPH AVENUE

BERKELEY, CALIFORNIA 94705

OFFICIAL BUSINESS

PENALTY FOR PRIVATE USE, \$300
POSTAGE AND FEES PAID

U. S. DEPARTMENT OF

AGRICULTURE

AGR 101

Return the mailing label(s) to above address if:

$\square$ Your name or address is wrong (indicate corrections, including ZIP).

- You receive duplicate copies (include labels from all copies received).

$\square$ You do NOT wish to continue receiving this technical series. 